\title{
A HISTORICAL PERSPECTIVE AND OPPORTUNITIES FOR DIETETICS EDUCATION, PRACTICE AND PROFESSIONAL ORGANIZATIONS IN THE CZECH REPUBLIC
}

\section{VÝVOJ VZDĚLÁVÁNÍ, PRAXE A PROFESNÍCH ORGANIZACÍ NUTRIČNÍCH TERAPEUTŮ V ČESKÉ REPUBLICE A JEJICH MOŽNOSTI DO BUDOUCNA}

\author{
Martin Krobot $^{1}$, Victoria Hawk ${ }^{2}$ (student), Veronika Spáčilová ${ }^{1}$ (student), Zlata Kapounová ${ }^{1}$ \\ ${ }^{1}$ Department of Public Health, Faculty of Medicine, Masaryk University, Brno, Czech Republic \\ ${ }^{2}$ Department of Nutrition, The University of North Carolina, Greensboro, United States of America
}

\begin{abstract}
Background: Food and nutrition play an essential role in human health. Evidence-based research supports the important role of dietitians providing medical nutrition therapy for the prevention, management and treatment of many diseases and conditions. Officially recognized in 1951, dietitians (formerly dietary nurses) have an important history in the Czech Republic.

Aim: This narrative review aims to examine the history of nutrition care in the Czech Republic and identify future opportunities for the development and contributions of dietitians. We include information about education, relevant legislation, licensure, scope of practice, the current workforce, and existing professional organizations. The article provides an assessment of the opportunities for the future development and professionalization of dietitians.

Methodology: We used licensed, electronic databases PUBMED, CINAHL, EBSCO, MEDVIK to search the professional literature as well as hand searching publications in both the Czech and English languages including current legislation and statistical information.

Results: Formal dietetics training has progressed from the preparation of therapeutic meals to university level programs offering science-based training with supervised clinical practice to prepare bachelor's and master's level dietitians. As a nationally recognized profession there are three professional associations supporting more than 2,500 dietitians in the Czech Republic. Despite these developments, the advancement of the profession remains inadequate due to a limited scope of practice, wide variation in education amongst dietitians, no requirements for licensure and underutilized competencies.

Conclusion: Despite the long history and development of this profession, dietitians in the Czech Republic remain an underutilized resource to provide a wide variety of nutrition services. Thus, in an effort to expand their scope of practice and improve nutrition care, further research is needed within the Czech Republic to demonstrate their essential role in the prevention, treatment and management of many diseases.
\end{abstract}

\section{KEY WORDS}

dietitian, dietary nurse, nutrition, scope of practice, education, allied health, history of dietetics

\section{INTRODUCTION AND LITERATURE REVIEW}

Dietitians are the health professionals with education and training in nutrition and dietetics (1). Evidence-based research documents the significant benefits of dietitians providing medical nutrition therapy (MNT) to improve health outcomes and reduce health care costs for various conditions including non-communicable diseases such as obesity and dia- betes $(1,2,3)$. In order to keep pace with the global advancements of the dietetics profession, the European Federation of the Association of Dietitians (EFAD) reports ongoing efforts for European Union (EU) member countries to follow a standardized system of education for dietitians and to allocate resources for coverage of dietitian services within the healthcare system (4). While a healthy diet was a part of spa ther- 
apy in the Czech lands centuries ago, over the past decades, like many countries around the world, the World Health Organization (WHO) reports rising rates of obesity and associated chronic diseases with nutrition as a risk factor $(5,6)$. So, what is the status of dietetics education and the role of dietitians in the Czech Republic? We conducted a literature search in PUBMED, CINAHL, EBSCO and MEDVIK using the search terms dietary nurses, dietitians, nutrition education, scope of practice, allied health, and the future of dietitians to assess this question. The history of education and the practice of Czech dietitians is documented in a few publications $(7,8,9)$. This is the first narrative review to summarize the available information including historical, legislative, and statistical data in order to present a comprehensive history, current assessment including challenges for the advancement of the profession and to propose a future path for Czech dietitians.

\section{Diet therapy in Czechoslovakia}

For hundreds of years nutrition has had a role in Czech medical care related to traditional spa treatments which included diet therapy. In 1522 Dr. Wenceslaus Payer wrote about the treatments found in the Czech spa town of Karlovy Vary where therapy regimens included not only spa treatments and the consumption of the local mineral waters, but also emphasized the patient's lifestyle and nutrition habits (9). Over the following centuries several books were written by doctors and professional chefs focusing on healthy nutrition, recipes and the use of special diets to treat disease (9). Perhaps the most important publication was A New Diet System for Hospitals (Nový dietní systém pro nemocnice) written by Dr. Přemysl Doberský (10), a general internist from Czechoslovakia. Published in 1955, this book was inspired by the hospital diet system in the Soviet Union and became the most prevalent standard for the preparation of therapeutic diets in hospitals and spas in Czechoslovakia (10). Doberskýs diet system (revised in 1968 and 1983) has endured for decades and its basic principles remain widely used in hospitals and other health care facilities throughout the Czech Republic. Significant progress has been made by the Ministry of Health in recent 2020 guidelines, which represent a true milestone in medical nutrition therapy recommendation including the update of therapeutic diets after a long period of time. The importance of this document lies in the promotion of current knowledge of evidence-based medicine and nutrition into clinical practice and in the promotion of changes aimed at improving institutional dietary systems (11). The proper use and prepa- ration of therapeutic diets remain an important part of the healthcare system and require not only updated guidelines, but also well-trained staff. Therefore, over the past decades there has been an evolution of the education system for dietetics professionals working in the Czech Republic.

\section{Education of dietary professionals}

A. Dietary workers (dietní pracovnice); 1934-1950

Despite the published recommendations for dietetics and therapeutic diets at the beginning of $20^{\text {th }}$ century (9), health facilities in Czechoslovakia did not have any workers trained to prepare food for patients with special dietary needs. Thus, in 1934 the Ministry of Health established the first school for the education of dietary workers in Prague (Vyšší škola pro vzdělávání dietních pracovnic) (8). The curriculum included cooking and therapeutic meal preparation along with math, Czech language, and some clinical subjects that were taught by medical doctors. The school started as a one-year program that was later extended to two years. During their training, the students gained practical experience by preparing standardized therapeutic meals for patients in the internal medicine clinic of Dr. Prusík (8). Upon graduation, the dietary workers were qualified to prepare therapeutic diets based on a doctor's prescription and most were employed in the food service departments of healthcare facilities (8). The cooperation between the school and Dr. Prusík's clinic demonstrated the essential role of dietary workers at that time.

During the post-war period in 1948 the Ministry of Education standardized the curriculum of the schools that provided education for health care professions to four years (12). All students received the same education during the first two years and discipline specific courses for years three and four (13). Students were admitted starting at the age of 15 and the program emphasized strict hygiene along with the respectful and ethical treatment of patients (8). Another school for practical dietetics was established in Brno (14), and by 1949 there were ten schools educating dietary workers in Czechoslovakia (8), thus demonstrating growth and interest in the profession.

\section{B. Dietary nurses (dietní sestry); 1951-2003}

The 1950's brought significant changes for health professionals through new legislation that designated responsibility for their education to the Ministry of Health $(13,15)$. More specifically, the graduates of these specialized colleges were recognized as midlevel health professionals and Dietary Workers were given the title of Dietary Nurse (DN) (15). The associ- 
ation of dietetics with nursing was important not only because the DNs were identified as healthcare professionals, but they also had new educational standards and practice guidelines. These included an education program that followed a standardized curriculum, the requirement to pass a standardized examination at graduation and job responsibilities based on a specific scope of practice $(15,16)$. DNs were employed as food service professionals and classified according to their scope of practice and level of responsibility with DN Managers as the most senior level professionals, followed by the Head of DNs and then DNs themselves (17). To support the professional growth and development of the healthcare workforce, starting in 1960 the National Centre for Nursing and Allied Health Professions (NCNAHP) managed the continuing education requirements for DNs and other allied health professionals. Furthermore, a decade later NCNAHP offered additional education to DNs providing them with an opportunity to earn specialized qualifications in Population Health Education or in Nutrition and Metabolic Disorders $(18,19)$. This aimed to support the advancement of the profession.

\section{Recognition of dietitians}

Despite some evidence that the SOP for DNs was increased over time (20), the perception of their role in healthcare remained that "Dietary nurses represent a very important profession, which is still underappreciated" (7). Their importance was demonstrated in 2004 when Czech legislation established a completely new system for the education, practice, and licensure of al- lied health professionals (AHPs) including dietitians. This law and its decrees designated the position of dietitians as a health profession and documented the necessary qualifications and scope of practice (SOP) $(21,22)$. In addition, it promoted the advancement of dietetics education by supporting university level programs for dietitians. These legislative changes further strengthened the professionalization of dietitians in the Czech Republic through enhancing in-country education programs, defining the SOP, and establishing licensure requirements for all AHPs. The requirement of a license to practice is an important form of recognition of AHPs and designed to protect the health and safety of the public by requiring that licensees meet minimum degrees of competence as well as ongoing lifelong learning requirements. An additional part of the new legislation was the determination that dietary nurses are now recognized as dietitians, too. This change of professional title happened overnight, without any further training or education required for the DNs. Therefore, after this turning point in 2004, there are currently three groups of dietitians in Czech Republic, all with the same SOP but having quite different levels of education - either high school (former dietary nurses), college (former certified dietary nurses or certified dietitians) or a bachelor's degree (university educated dietitians) (Figure 1). Additionally, former dietary nursing study programs at high schools were transformed into programs preparing dietetic technicians - a profession with a similar SOP. However, dietetic technicians are required to work under the supervision of a dietitian (21).

Figure 1. The education of a dietitian

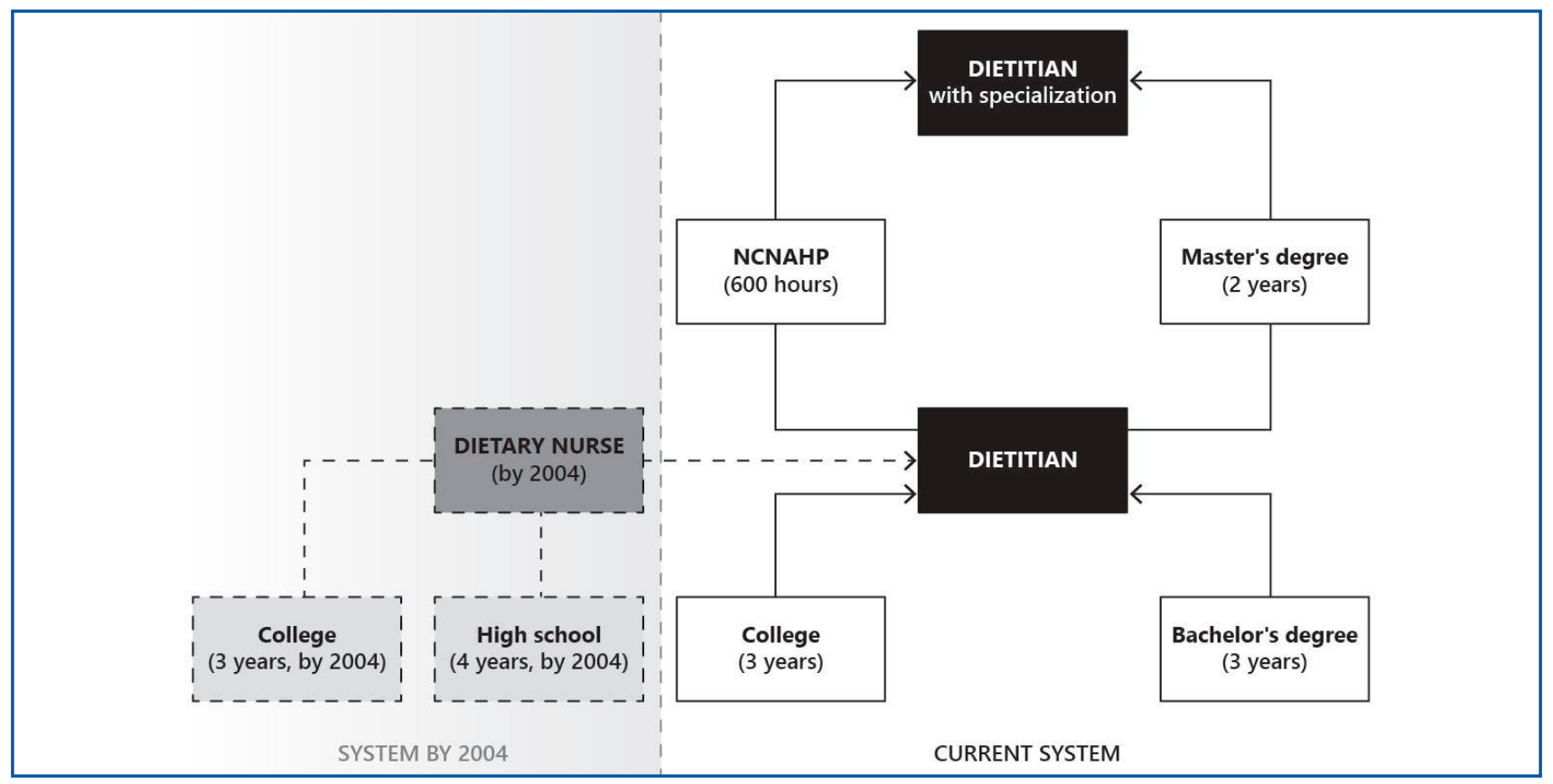


As shown in figure 1, since 2004, there are currently two ways to become a dietitian: graduating from a college (a specialist with diploma) or a university (bachelor's degree), both of them offering three-year study programs (21). Despite some previous efforts in 1990s, the first bachelor programs of dietetics started in 2007 at the $1^{\text {st }}$ Faculty of Medicine, Charles University, Prague, and in 2008 at the Faculty of Medicine, Masaryk University, Brno (23, 24, 25). Currently, there are five faculties of four universities (Brno, České Budějovice, Prague, and Ostrava) and seven colleges educating new dietitians according to a curriculum decree and dietetic qualification standard $(26,27,28)$.

Furthermore, all groups of dietitians can earn a specialized qualification by completing an additional study program at NCNAHP or by completing the university level 2-year master's degree study program in Brno or Prague which is only open to university graduates. Starting with 'Population Health Education' in 1971 (18) and 'Nutrition and Metabolic Disorders' in 1981 (19), the system of specializations for dietary nurses remained the same until 2004. In this year, coming along with the profession of a dietitian, new fields of specialization for dietitians were introduced - 'Nutrition of Children', 'Community Nutrition Care' and 'Intensive Care Nutrition' (29). The specializations merged in 2010 into 'Nutrition of Children' and 'Nutrition of Adults' (30), until a sole program 'Nutrition of Adults and Children' was approved in 2018 (31) with its obligatory curriculum issued in the Bulletin of the Ministry of Health in November 2019 (32).

Since the specialization study program in NCNAHP is open for any dietitian, the outcome is the same as stated above resulting in four types of dietitians with the same SOP (i.e. specialized high school graduate, specialized college graduate, specialized bachelor graduate and master graduate). This concurrence has been criticised by the National Health 2020 Strategy for CR which identifies that the current training for AHPs with different education levels but without any difference in SOP is non-effective and a waste of money allocated for pregradual education (6). Despite these concerns, to date there has been little progress with no proposed amendments to the law.

\section{Dietitian's scope of practice}

The transfer of SOP from a dietary nurse to a dietitian in 2004 meant a step forward in terms of redirecting from food service more to the clinical expertise, however, the shift could have been more substantial. In general, granting new privileges to allied health pro- fessionals in CR is a slow process and the SOP declared in 2004 hasn't changed since then. It includes clinical skills such as taking a patient's nutrition history, examining the patient's nutritional status, offering nutrition education to the patient, and the development of meal plans (both individually and for the facility). Specialized dietitians can also prepare nutrition education materials, assess a patient's nutritional status, train other health professionals in nutrition, and conduct research (Table 1). Unfortunately, we don't know whether dietitians in the hospitals across the CR are allowed to align with this SOP or what they actually do as there is no research on this topic available (time-motion studies, qualitative research etc.).

Furthermore, the terminology used in the legislation tends to be confusing and unclear, causing further problems in practice (an example can be seen in the nutrition status assessment, where dietetic technicians have broader SOP than dietitians). Unlike the United States (33), Czech Republic is lacking an exact definition of terms, the terminology in legislation differs from the one used in practice and its explanation is up to the reader.

Regarding a patient's diet order or clinical nutrition needs including oral nutrition supplements (ONS), tube feeding, and parenteral nutrition, these can be prescribed by the attending physician based on the dietitian's recommendation (34). In outpatient settings, the dietitian cooperates with the MD Nutritionist, who is the bearer of the functional licence F016 issued by the Czech Medical Chamber, and the only medical professional with the authority to prescribe all the means of enteral (ONS, tube feeding) and parenteral nutrition for outpatients (35). Other doctors including oncologists, geriatricians and surgeons are authorized to prescribe ONS for patients, but only for a limited number of choices on the formulary (36).

The practical skills to fulfil the activities above are obtained via the pregradual education, as programs educating dietitians have to contain at least 1800 hours of practical education, which comprises also 480 hours of clinical placement required by the qualification standard (28). However, the limited amount of practicing dietitians in healthcare settings (see Current Workforce) poses a challenge for providing high quality practice placements for all the dietetic students in CR.

\section{Legal protection of dietitians}

Dietitians study a wide variety of courses focusing on food, nutrition, counselling, and management and the purpose of following a standardized education program and requiring a license is to protect the nutri- 
Table 1. Scope of practice of different dietitians according to their level of education (34)

\begin{tabular}{|c|c|c|c|c|c|c|c|c|c|c|}
\hline \multirow[b]{2}{*}{ Scope of practice } & \multirow[b]{2}{*}{ DN } & \multirow[b]{2}{*}{ DT } & \multicolumn{3}{|c|}{ Not specialized } & \multicolumn{4}{|c|}{ Specialized } & \multirow[b]{2}{*}{ MD } \\
\hline & & & HS & Dis. & Bc. & HS & Dis. & Bc. & Mgr. & \\
\hline \multicolumn{11}{|l|}{ Food service } \\
\hline Meal plans & $\mathrm{Y}$ & $\mathrm{Y}$ & $\mathrm{Y}$ & $\mathrm{Y}$ & $\mathrm{Y}$ & $\mathrm{Y}$ & $\mathrm{Y}$ & $\mathrm{Y}$ & $\mathrm{Y}$ & \\
\hline Meal preparation & $\mathrm{Y}$ & $\mathrm{Y}^{*}$ & $\mathrm{Y}$ & $\mathrm{Y}$ & $\mathrm{Y}$ & $\mathrm{Y}$ & $\mathrm{Y}$ & $\mathrm{Y}$ & $\mathrm{Y}$ & \\
\hline Food service management & $\mathrm{Y}$ & & $\mathrm{Y}$ & $\mathrm{Y}$ & $\mathrm{Y}$ & $\mathrm{Y}$ & $\mathrm{Y}$ & $\mathrm{Y}$ & $\mathrm{Y}$ & \\
\hline \multicolumn{11}{|l|}{ Assessment } \\
\hline Nutritional history taking and evaluation & & & $\mathrm{Y}$ & $\mathrm{Y}$ & $\mathrm{Y}$ & $\mathrm{Y}$ & $\mathrm{Y}$ & $\mathrm{Y}$ & $\mathrm{Y}$ & \\
\hline Nutritional status examination & & & $\mathrm{Y}$ & $\mathrm{Y}$ & $\mathrm{Y}$ & $\mathrm{Y}$ & $\mathrm{Y}$ & $\mathrm{Y}$ & $\mathrm{Y}$ & \\
\hline Nutritional status assessment & & $\mathrm{Y}^{*}$ & & & & $\mathrm{Y}^{* *}$ & $Y^{* \star}$ & $Y^{* *}$ & $\mathrm{Y}^{* *}$ & \\
\hline Per os dietary assessment & & & $\mathrm{Y}$ & $\mathrm{Y}$ & $\mathrm{Y}$ & $\mathrm{Y}$ & $\mathrm{Y}$ & $\mathrm{Y}$ & $\mathrm{Y}$ & \\
\hline Nutritional intake documentation & & $\mathrm{Y}$ & & & & & & & & \\
\hline Nutritional calculations & & $\mathrm{Y}$ & & & & & & & & \\
\hline \multicolumn{11}{|l|}{ Care } \\
\hline Diet assignment & & & & & & & & & & $\mathrm{Y}$ \\
\hline Individual meal plan composition & & $\mathrm{Y}^{*}$ & $\mathrm{Y}$ & $\mathrm{Y}$ & $\mathrm{Y}$ & $\mathrm{Y}$ & $\mathrm{Y}$ & $\mathrm{Y}$ & $\mathrm{Y}$ & \\
\hline Education & $\mathrm{Y}$ & $\mathrm{Y}$ & $\mathrm{Y}$ & $\mathrm{Y}$ & $\mathrm{Y}$ & $Y^{* * *}$ & $Y^{* * *}$ & $Y^{* \star *}$ & $Y^{* \star *}$ & \\
\hline Education materials creation & & & & & & $\mathrm{Y}$ & $Y$ & $\mathrm{Y}$ & $\mathrm{Y}$ & \\
\hline \multicolumn{11}{|l|}{ Facility } \\
\hline Training of other employees & & & & & & $\mathrm{Y}$ & $Y$ & $\mathrm{Y}$ & $Y$ & \\
\hline Quality assessment & & & & & & $\mathrm{Y}$ & $\mathrm{Y}$ & $\mathrm{Y}$ & $\mathrm{Y}$ & \\
\hline Research on site & & & & & & $\mathrm{Y}$ & $\mathrm{Y}$ & $\mathrm{Y}$ & $\mathrm{Y}$ & \\
\hline Teaching in specialization courses & & & & & & $\mathrm{Y}$ & $\mathrm{Y}$ & $\mathrm{Y}$ & $\mathrm{Y}$ & \\
\hline \multicolumn{11}{|l|}{ Artificial nutrition } \\
\hline \begin{tabular}{|l|} 
EN prescription \\
\end{tabular} & & & & & & & & & & $\mathrm{Y}$ \\
\hline PN prescription & & & & & & & & & & $\mathrm{Y}$ \\
\hline
\end{tabular}

Caption: DN - dietary nurse; DT - dietetic technicians; HS - high school; DiS. - college degree; Bc. - bachelor's degree; Mgr. - master's degree; MD - medical doctor; Y - yes; ${ }^{\star}$ not in special diets/complicated diseases; ${ }^{\star \star}$ in order to identify possible complications; ${ }^{* * *}$ also in special diets

tional health, safety, and welfare of the public by encouraging high standards of performance in the profession (37). For example, in the United States, most states require dietitians to be licensed and their practice is protected and exclusive for dietitians (38). From 2004 to 2017 the CR required a license and ongoing education for AHPs including dietitians (21), but legislative changes enacted in 2017 cancelled the requirements for licensure as well as ongoing lifelong learning for dietitians (39). Unfortunately, this legislative change compromises two key elements designed to protect the welfare of the public and support the development of health professionals, including dietitians. Removing licensure requirements hinders the mechanism to manage the minimum standards of competency for health professionals and without continuing education requirements, AHPs can continue to practice without remaining current about professional developments and research. Additionally, in the Czech Republic, the only protection identified is the use of the term "dietitian" as no one except for the designated professionals can use this name (21). However, dietitians in private practice do not have practice exclusivity guaranteed and unfortunately many lay people do not realize the difference between a dietitian (AHP) and a nutritionist (not a health care professional without following the standardized education and training in dietetics).

The legislative position of Czech dietitians is also often compromised internationally. Lacking the official definition and translation of terms, the Czech term for a dietitian (i.e. nutriční terapeut) often tends to be translated as 'nutritional therapist' or 'nutritionist' even in official settings, which is not accurate regarding the scope of practice fulfilling the EFAD's definition of a dietitian (40). This results e.g. in the wrong classification of Czech dietitians in the REGPROF database, thus complicating the international workforce mobility.

\section{Current workforce}

Along with other AHPs, in 1951 DNs were classified as mid-level health professionals and according to chart 1 , their numbers in healthcare facilities gradually increased starting in 1957 and doubled by 1983 (3.67 to $7.44 \mathrm{DNs} / 10^{5}$ population) (41). Despite some inexplicable variability over the following decades, at 8.05 dietitians per 100,000 population in 2019 , the number of dietitians reported in $\mathrm{CR}$ is comparable 
to other developed countries. Although the US, UK and Austria reported more dietitians in the workforce with 23,13 and 9 respectively per 100,000 population, other European countries such as Germany, France and Belgium reported fewer with 4, 4, and 6 dietitians respectively. $(41,42)$

\section{Chart 1. Nutrition workforce (1957-2019) (41)}

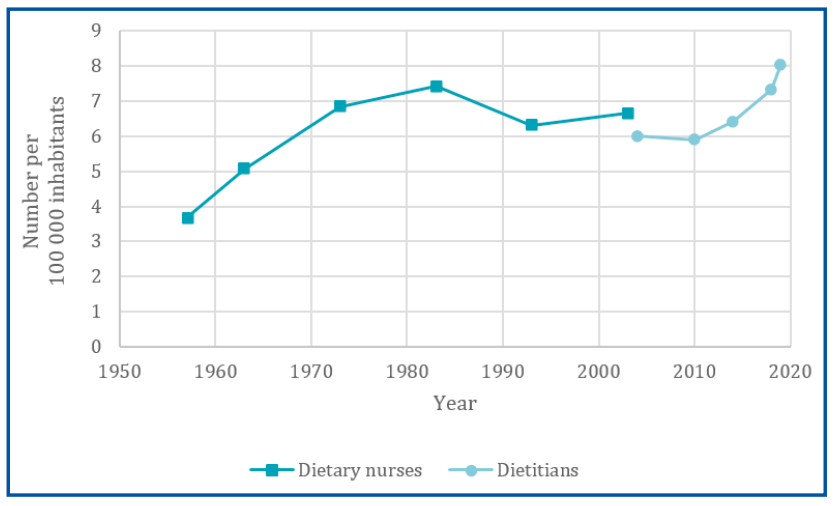

In October 2019, there were 2566 dietitians registered with 857 (33.4\%) dietitians employed in healthcare facilities and a median age of 40-44 years (43). With no employment registry outside of healthcare and social services, it is not possible to confirm the employment of other dietitians, but it is likely that they are working in private practice, or in many other areas, e.g. National Institute of Public Health, Ministry of Health, education institutes, school canteen services, agriculture, food and pharmacy industry and others.

Additionally, there were 428 dietetic technicians with only $33(7.7 \%)$ of them employed in the healthcare facilities (43). Employment information for dietitians remains limited due to lack of registries as well as limited participation in the professional organizations in the Czech Republic.

\section{Professional organizations for dietitians}

Currently there are three professional organizations representing the dietitians in the Czech Republic, each differing in their genesis, membership, goals, and activities. The organisations are listed chronologically in the order they were established, with the membership of dietitians concentrated between two associations, the Section of Dietitians as a part of the Czech Association of Nurses and the Czech Association of Dietitians.

\section{Section of dietitians as a part of the czech associ- ation of nurses / \\ Sekce nutričních terapeutů české asociace sester}

Historically the oldest professional organization of dietitians is the Section of Dietitians, as a part of the
Czech Association of Nurses (SD CAN), which was established in 1992 (44). This section brings together dietitians and dietetic technicians working in health and social care facilities, education, and counselling services, as well as students and retired members. The 2019 Annual report documents 190 members in SD CAN (45). Their goals include strengthening the role of dietitians in support of the current legislation, increasing the salary of dietitians, providing easy availability of professional information, and improving awareness of SD CAN activities (44).

\section{Section of nutrition and nutrition care / Sekce výživy a nutriční péče}

The Section of Nutrition and Nutrition Care (SNNC) was established in 2016. It is a multi-professional organization that is open to nutrition experts (including dietitians), specialists in other disciplines and students. The Annual Report was not available for review, and there was no information about the number of members. Its goals are broad and include information about increasing the expertise of members, educational programs about health and nutrition for the population. To fulfil these goals, SNNC reports organizing conferences, supporting cooperation with other organizations and publishing education materials (46).

\section{Czech association of dietitians / \\ Česká asociace nutričních terapeutů}

Founded in 2018, the Czech Association of Dietitians (CAD) is an independent organization with a membership that consists of dietitians and dietetic students (future dietitians). In 2019 CAD had 70 members and became an associate member of EFAD. Through the affiliation with EFAD, CAD brings Czech dietitians the opportunity for international collaboration with European dietitians. The aims of CAD include improving nutritional care in the Czech Republic through greater involvement of its members, creating opportunities for the application of their skills and knowledge, constantly increasing the expertise of its members, cooperation with other professionals and involvement in European and global professional structures (47). In 2020, the CAD merged with the Association of Dietetic Students, creating a platform for the self-actualization of future dietitians (48).

\section{DISCUSSION AND THE FUTURE}

\section{OF DIETITIANS IN THE CZECH REPUBLIC}

Despite the long history of nutrition care and the current training for dietitians, there can still be identified gaps in the system, including legislation, SOP, education, and nutrition care, which are challenging the 
advancement of the profession. University educated dietitians are trained to apply evidence-based knowledge about food and nutrition to assess (49), counsel and educate patients about prevention, treatment, and management of nutrition-related disorders, also known as Medical Nutrition Therapy (MNT) $(1,33)$. Current research documents the significant benefits of dietitians providing the various components of MNT to improve health outcomes and reduce health care costs for various diseases including diabetes, cardiovascular disease, obesity, and malnutrition $(1,2,3)$. While published nutrition research in CR has identified the increasing prevalence of nutrition related health concerns including obesity, cardiovascular disease and malnutrition (5,50-53), it lacks information about the nutrition care provided by dietitians. Developing strategies to prevent and treat nutrition related conditions represent opportunities for dietitians to work as part of multidisciplinary teams $(54,55)$. Thus it is time to identify and improve understanding about the current practices of dietitians related to their existing SOP and assess the impact and opportunities for improving nutrition related health outcomes in CR. More specifically, with evidence demonstrating that obesity related nutrition care provided by qualified dietitians is cost effective in other countries by saving an estimated $€ 14-63$ for every 1 spent over 5 years (56, $57,58)$, research is needed in CR to assess the roles of dietitians and promote adequate staffing and SOP in hospitals and clinics. Collaboration between nutrition experts in various sectors can support the research to assess the situation, identify opportunities for improvement and promote appropriate changes to legislation.

In addition, the current legislation creates an unnecessary burden on doctors in the Czech healthcare system to provide optimal nutrition care. Preliminary research from the Masaryk University Medical School identifies that future doctors report a lack of nutrition education and limited awareness about the role of di- etitians in the hospital setting $(59,60)$. Dietitians are educated and trained about the use of MNT including therapeutic meals and supplements for the management, treatment and prevention of various diseases. Thus, as is consistent with the practice in other countries, modifying the SOP for qualified dietitians to include ordering privileges for therapeutic diets and supplements will utilize their education and training and further support the role of doctors by allowing them to focus on other aspects of patient care and thus improving nutrition care in the CR (61). Furthermore, facilitating the reimbursement for nutrition services from insurance companies presents another opportunity for improving patient access to qualified dietitians for MNT. By involving dietitians on the interdisciplinary healthcare team, there is an opportunity for improving nutrition care in the CR (62). Additionally, by promoting participation in the professional organizations as well as networking and collaborations with dietitians and associations in other countries, there are many opportunities for dietitians as well as for the future nutrition professionals in the CR. Specifically through involvement with EFAD's student section, European Network of Dietetic Students (ENDietS) (63), future dietitians can raise awareness and connect with dietetic students from other European universities and high schools to spread awareness about the important work of dietitians and promote research to demonstrate the benefits of promoting optimal nutrition care.

Overall, the profession is evolving as evidenced by the significant events associated with the development of the dietetics profession in the Czech Republic (Figure 2). It is clear that the 50-year long tradition of Dietary Nurses as compared to the 16-year modern history of Dietitians has had an impact on their current position and perception by the public and healthcare professionals. Despite gradual successes in this profession, such as the growing number of Dietitians (Chart 1) and their increasing professional qualifica-

Figure 2. Key milestones for dietitians in the Czech Republic

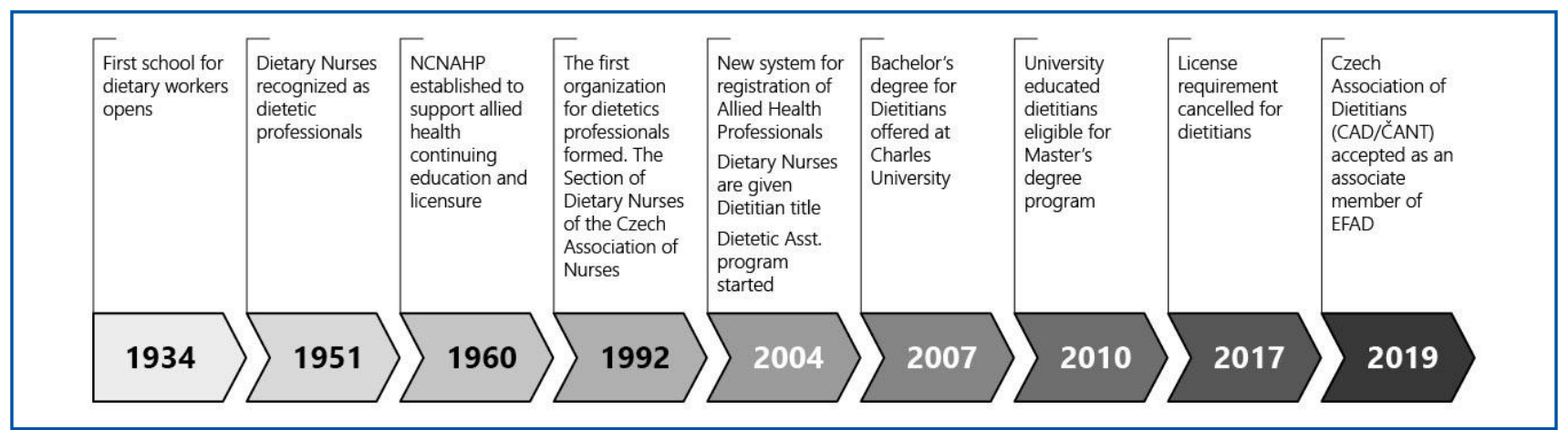


tions, there are still opportunities for improvement. To strengthen the position of Dietitians among the allied health professions, it is necessary to document their important contributions with valid research conducted in the CR. These data can support efforts to initiate the necessary changes promoting Dietitians as qualified health professionals and improve the quality of nutritional care provided in the Czech Republic.

\section{ACKNOWLEDGMENTS}

The creation of this paper was supported by the Masaryk University Grant Agency: MUNI/A/1608/2020.

\section{REFERENCES}

1. European Federation of the Associations of Dietitians. Sustainable Health Through the Lifespan [Internet]. 2019 [cited 2020 Dec 17]. Available from: http://www.efad.org/media/1832/efad-sustainable-health-through-life-span-2019.pdf

2. Howatson A, Wall C, Turner-Benny P. The contribution of dietitians to the primary health care workforce. J Prim Health Care. 2015 Dec;7(4):324.

3. Pastors JG, Warshaw H, Daly A, Franz M, Kulkarni K. The Evidence for the Effectiveness of Medical Nutrition Therapy in Diabetes Management. Diabetes Care. 2002 Mar 1;25(3):608-13.

4. European Federation of the Association of Dietitians. European Academic and Practitioner Standards for Dietetics [Internet]. 2005 [cited 2020 Dec 16]. Available from: http://www.efad.org/ media/1442/efad_benchmarkjune2005_uk.pdf

5. Čapková N, Lustigová M, Kratěnová J, Žejglicová K. Zdravotní stav české populace: výsledky studie EHES 2014 [Internet]. Praha: Státní zdravotní ústav; 2016 [cited 2020 Dec 18]. Available from: http://www.szu.cz/uploads/documents/chzp/ ehes/EHES_2014.pdf

6. Ministerstvo zdravotnictví ČR. Zdraví 2020 - Národní strategie ochrany a podpory zdraví a prevence nemocí [Internet]. Praha: Ministerstvo zdravotnictví ČR; 2014 [cited 2019 Dec 18]. Available from: https://www.mzcr.cz/wp-content/ uploads/wepub/8690/20840/Zdrav\%C3\%AD\%20 2020_N\%C3\%A1 rodn\%C3\%AD\%20strategie\%20 ochrany\%20a\%20podpory\%20zdrav\%C3\%AD\%20 a\%20prevence\%20nemoc\%C3\%AD....pdf

7. Pavlíčková J. Dietní sestra - vysoce odborná profese. Sestra. 2000;10(4):3.

8. Pavlíčková J. Čas pro sekci nutričních terapeutů. Florence. 2009; Nov 5;5(11):6-8.

9. Krajíčková K. Diety a dietní systémy od konce 19. století po dnešek. Časopis praktických lékařu pro děti a dorost. 2013 Mar;13(3):26-7.
10. Doberský P. Nový dietní systém pro nemocnice. 1. ed. Praha: Státní zdravotnické nakladatelství; 1955.

11. Těšínský $\mathrm{P}$, Novák F, Pražanová I, Růžičková L, Karbanová M, Krobot M, et al. Metodické doporučení pro zajišstění stravy a nutriční péče. Věstník MZ ČR. 2020 Sep 30;2020(10):2-45.

12. Act No. $95 / 1948 \mathrm{Sb}$. on basic setting of the unified education system.

13. Kutnohorská J. Historie ošetřovatelství. 1. ed. Praha: Grada; 2010.

14. Miloševičová K. Střední zdravotnická škola a Vyšší odborná škola zdravotnická Brno, Merhautova [Internet]. Historie zdravotnické školy v Merhautově ulici. [cited 2020 Dec 14]. Available from: https://www.szsbrno.cz/historie-skoly\#historie_m

15. Decree No. 77/1951 Sb. on mid-level healthcare professionals.

16. Decree No. $44 / 1966 \mathrm{Sb}$. on allied health professionals and other professionals in healthcare.

17. Starnovská T. Odborníci na klinickou výživu se vzdělávají už 80 let. Florence. 9(6):46-7.

18. Decree No. 72/1971 Sb. on allied health professionals and other professionals in healthcare.

19. Decree No. 77/1981 Sb. on allied health professionals and other professionals in healthcare.

20. Kužela L, Starnovská T. Standardy pro podávání nutriční podpory a pro výživu v nemocnici. Diabetologie, metabolismus, endokrinologie, výživa. 2002;5(2):111-21.

21. Act No. $96 / 2004 \mathrm{Sb}$. on the allied health professions.

22. Decree No. 424/2004 Sb. on the scope of practice of allied health professionals and other professionals in healthcare.

23. Douglas PD, Beeman SJ. Training in Dietetics: New Partnerships in the Czech Republic and Moldova. Journal of the American Dietetic Association. 1996 Jan 9;96(9):A-83.

24. Masarykova univerzita, Lékařská fakulta. Studijní katalog na Lékařské fakultě $\mathrm{v}$ akademickém roce 2008/2009: Specializace ve zdravotnictví, Ošetřovatelství. 2008.

25. Univerzita Karlova v Praze, 1. lékařská fakulta. Výroční zpráva 2007 [Internet]. 2007 [cited 2020 Dec 18]. Available from: https://www.lf1.cuni.cz/ document/20898/vyrocni-zprava-lf-uk-2007-cz.pdf

26. Česká asociace nutričních terapeutů [Internet]. Jak se stát nutričním terapeutem. [cited 2021 Jan 1]. Available from: https://www.cant.cz/ jak-se-stat-nutricnim-terapeutem/

27. Decree No. 39/2005 Sb. determining the minimal requirements for study programmes leading to professional qualification for the discharge of allied health professions. 
28. Kvalifikační standard přípravy na výkon zdravotnického povolání: Nutriční terapeut. Věstník MZ ČR. 2019 Sep;2019(9):29-55.

29. Government Decree No. 463/2004 Sb. declaring the areas of education and professional titles of the specialized healthcare workers.

30. Government Decree No. 31/2010 Sb. declaring the areas of education and professional titles of the specialized healthcare workers.

31. Government Decree No. 164/2018 Sb. amending the Government Decree No. 31/2010 Sb. declaring the areas of education and professional titles of the specialized healthcare workers.

32. Ministerstvo zdravotnictví ČR. Vzdělávací program specializačního vzdělávání v oboru nutriční terapeut - výživa dospělých a dětí. Věstník MZ ČR. 2019 Nov;2019(11):30-56.

33. Academy of Nutrition and Dietetics. Academy of Nutrition and Dietetics Definition of Terms List [Internet]. 2021 [cited $2021 \mathrm{Mar}$ 28]. Available from: https://www.eatrightpro.org/-/media/eatrightpro-files/practice/scope-standards-of-practice/academydefinitionoftermslist.pdf

34. Decree No. 55/2011 Sb. on the scope of practice of allied health professionals and other professionals in healthcare.

35. Česká lékařská komora. Stavovský předpis č. 12 České lékařské komory [Internet]. 2000 [cited 2020 Dec 18]. Available from: https://www.lkcr. cz/stavovsky-predpis-clk-c-12-363.html

36. Státní ústav pro kontrolu léčiv. Seznam cen a úhrad LP/PZLÚ k 1.8.2020 [Internet]. 2020 [cited 2020 Aug 14]. Available from: https://www.sukl.cz/ sukl/seznam-cen-a-uhrad-lp-pzlu-k-1-8-2020

37. Hwalla N, Koleilat M. Dietetic practice: the past, present and future. East Mediterr Health J. 2004;10(6): 16.

38. Eat Right Pro Academy of Nutrition and Dietetics [Internet]. Licensure and Professional Regulation of Dietitians. 2020 [cited 2020 Dec 2]. Available from: https://www.eatrightpro.org/advocacy/licensure/ professional-regulation-of-dietitians

39. Act No. 201/2017 Sb. amending the Act No. 96/2004 Sb. and the Act No. 95/2004 Sb.

40. European Federation of the Associations of Dietitians. Dietitians in Europe: Definition, Profession and Education. Statement by the European Federation of the Associations of Dietitians (EFAD) [Internet]. 2016 [cited 2021 Mar 31]. Available from: http://www.efad.org/media/1128/revised-definition-of-a-dietitian.pdf

41. Ústav zdravotnických informací a statistiky ČR [Internet]. Knihovna a archiv: Zdravotnická ročenka České republiky. [cited 2020 Mar 27]. Available from: https://www.uzis.cz/index.php? pg=vystupy--knihovna\&id $=275$

42. International Confederation of Dietetic Associations. Dietitians-nutritionists around the world: Their education and their work [Internet]. 2016 [cited $2020 \mathrm{Jul}$ 15]. Available from: https://www. internationaldietetics.org/Downloads/2016-ICDA-Education---Work-report.aspx

43. Národní registr zdravotnických pracovníků. Ústav zdravotnických informací a statistiky; 2019. Report No.: Praha.

44. Sekce nutričních terapeutů ČAS [Internet]. O nás. [cited 2020 Dec 14]. Available from: https://www. nutricniterapeuti.cz/clanky/o-nas/

45. Česká asociace sester. Výroční zpráva [Internet]. 2019 [cited 2020 Sep 4]. Available from: https:// www.cnna.cz/docs/tiskoviny/vz-cas-2019final.pdf

46. Sekce výživy a nutriční péče [Internet]. [cited 2020 Dec 14]. Available from: https://www.sekce-vnp.cz

47. Česká asociace nutričních terapeutů. Výroční zpráva 2019 [Internet]. 2020 Jun [cited 2021 Jan 2]. Available from: https://www.cant.cz/wp-content/uploads/2020/07/V\%C3\%BDro\%C4\%8Dn\%C3\%A1-zpr\%C3\%A1va-2019-FINAL1.pdf

48. Česká asociace nutričních terapeutů [Internet]. [cited 2021 Jan 2]. Available from: https://www. cant.cz/

49. EFAD's Research and Evidence Based Practice Committee. Practice and Research: a perfect dietetic match [Internet]. 2020 [cited 2020 Nov 18]. Available from: http://www.efad.org/media/1974/ efad-factsheet_practice-and-research-a-perfectdietetic-match_2020.pdf

50. Brabcová I, Trešlová M, Bártlová $S$, Vacková J, Tóthová V, Motlová L. Risk Factors for Malnutrition in Seniors Aged 75+ Living in Home Environment in Selected Regions of the Czech Republic. Central European Journal of Public Health. 2016 Sep;24(3):206-10.

51. Rambousková J, Slavíková M, Krsková A, Procházka B, Andel M, Dlouhý P. Nutritional Status Assessment of Institutionalized Elderly in Prague, Czech Republic. Annals of Nutrition and Metabolism. 2013;62(3):201-6.

52. Lustigova M, Dzurova D, Pikhart H, Kubinova R, Bobak M. Cardiovascular health among the Czech population at the beginning of the $21 \mathrm{st}$ century: a 12-year follow-up study. Journal of Epidemiology and Community Health. 2018 May;72(5):442-8. 
53. Sigmund E, Badura P, Sigmundová D, Voráčová J, Zacpal J, Kalman M, et al. Trends and correlates of overweight/obesity in Czech adolescents in relation to family socioeconomic status over a 12-year study period (2002-2014). BMC Public Health [Internet]. 2018 Dec [cited 2018 Nov 9];18(1). Available from: https://bmcpublichealth.biomedcentral.com/ articles/10.1186/s12889-017-5013-1

54. Davis AM, Affenito SG. Interprofessional Education to Create and Sustain High-Performance Teams to Support Our Transforming Health Care System and Future Educational Model: How Nutrition and Dietetics Can "Weigh-in." Journal of the Academy of Nutrition and Dietetics. 2017 Dec;117(12):1871-6.

55. Hark LA, Deen D. Position of the Academy of Nutrition and Dietetics: Interprofessional Education in Nutrition as an Essential Component of Medical Education. Journal of the Academy of Nutrition and Dietetics. 2017 Jul;117(7):1104-13.

56. Sun Y, You W, Almeida F, Estabrooks P, Davy B. The Effectiveness and Cost of Lifestyle Interventions Including Nutrition Education for Diabetes Prevention: A Systematic Review and Meta-Analysis. J Acad Nutr Diet. 2017 Mar;117(3):404-421.e36.

57. Sikand G, Cole RE, Handu D, deWaal D, Christaldi J, Johnson EQ, et al. Clinical and cost benefits of medical nutrition therapy by registered dietitian nutritionists for management of dyslipidemia: A systematic review and meta-analysis. J Clin Lipidol. 2018 Sep;12(5):1113-22.

58. Kristensen MB, Dieperink KB, Rossau HK, Egholm CL, Viggers L, Bertelsen BM, et al. Dietary interventions in cardiac rehabilitation - The gap between guidelines and clinical practice. Clin Nutr ESPEN. 2018 Oct;27:120-6.

59. Hawk VH, Lauren H, Spáčilová V, Lagová E, Podborská M, Kapounová Z. Perceptions of nutrition education and the role of dietitians at a medical school in the Czech Republic: preliminary results. In EFAD Conference 2019, Berlin; 2019.

60. Kapounová Z, Hawk V. An assessment of nutrition education - review of general medicine curriculum at medical faculty of Masaryk University. In: Abstract Book [Internet]. Annual Meeting of The International Society of Behavioral Nutrition and Physical Activity, Prague; 2019 [cited 2020 Sep 11]. p. 995. Available from: http://isbnpa2019. venuewest.com/program/program-overview/

61. Skipper A. Clinical Privileging for Dietitians: A Vehicle for Efficient Nutrition Care. Clinical Nutrition Insight. 2009;35(7):1-4.
62. Cederholm T, Barazzoni R, Austin P, Ballmer P, Biolo G, Bischoff SC, et al. ESPEN guidelines on definitions and terminology of clinical nutrition. Clin Nutr. 2017 Feb;36(1):49-64.

63. European Federation of the Association of Dietitians [Internet]. Students. [cited 2020 Dec 10]. Available from: http://www.efad.org/en-us/students/

THE MAIN (CORRESPONDING) AUTHOR: Mgr. Martin Krobot Department of Public Health Faculty of Medicine, Masaryk University Kamenice 5, 62500 Brno CZ-625 00 BRNO krobot@med.muni.cz +420725159428 